\title{
Hubungan kemampuan keteknikan dan pedagogical knowledge dengan kompetensi pedagogik abad 21 pada mahasiswa S1 PTI FT UM
}

\author{
Rizka Afdalia, Setiadi Cahyono Putro *, Wahyu Sakti Gunawan Irianto \\ Universitas Negeri Malang, Jl. Semarang No. 5 Malang, Jawa Timur, Indonesia \\ *Penulis korespondensi, Surel: setiadi.c.p@ft.um.ac.id
}

Paper received: 03-01-2021; revised: 15-01-2021; accepted: 30-01-2021

\begin{abstract}
Abstrak
Penelitian ini bertujuan untuk mengetahui hubungan antara kemampuan keteknikan (X1), pedagogical knowledge (X2), dan kompetensi pedagogik abad 21 (Y) pada mahasiswa calon guru S1 PTI Universitas Negeri Malang. Penelitian ini menggunakan rancangan deskriptif korelasional yang bersifat kuantitatif. Sampel penelitian adalah mahasiswa calon guru S1 PTI Universitas Negeri Malang yang telah melaksanakan KPL sejumlah 102 mahasiswa. Teknik pengumpulan data variabel X1 dan X2 pada penelitian menggunakan dokumentasi data nilai akhir, sementara variabel Y menggunakan angket. Hasil penelitian menunjukkan bahwa: (1) kompetensi pedagogik abad 21 dikategorikan tinggi; (2) kemampuan keteknikan dikategorikan sedang; (3) pedagogical knowledge dikategorikan sangat tinggi; (4) terdapat hubungan positif dan namun tidak signifikan antara X1 dengan Y; (5) terdapat hubungan positif dan signifikan antara X2 dengan Y; (6) terdapat hubungan positif dan signifikan antara X1 dan X2 secara simultan dengan Y.
\end{abstract}

Kata kunci: kompetensi pedagogik abad 21; kemampuan keteknikan; pedagogical knowledge.

\section{Pendahuluan}

Abad 21 dikenal sebagai era pengetahuan ataupun knowledge age. Adanya abad pengetahuan men- jadikan perbahan pula di dunia pendidikan. Abad 21 ditandai juga dengan kemajuan di bidang TIK. Hal tersebut menjadikan pendidikan di Indonesia harus dikaitkan dengan teknologi yang nantinya dipergunakan untuk pembelajaran (Tridiana \& Rizal, 2020). Guru memiliki peran penting dalam kemajuan pendidikan, terutama mempersiapkan peserta didiknya dalam menghadapi tantangan abad 21 dengan meningkatkan keterampilan abad

21 perserta didik (Redhana, 2019). Pendidikan abad 21 guru dituntut untuk menguasai kompetensi guru abad 21 serta mampu menyesuaikan diri dengan tuntutan pendidikan abad 21.

Federasi Serikat Guru Indonesia (FSGI) menilai bahwa kompetensi guru di Indonesia masih tergolong rendah. Rerata nilai UKG guru belum mencapai standar kompetensi minimal yang ditentukan pemerintah yakni 70. Pada tahun 2017, rerata nilai UKG guru TK 68,23; guru SD 6,.22; guru SMP 67,76; guru SMA 69,55; dan rerata nilai UKG nasional mencapai 66,94. Dengan nilai rerata UKG yang mencapai 66,94 sementara untuk standar kompetensi minimalnya adalah 70, maka dapat disimpulkan kompetensi guru di Indonesia masih rendah. Sehingga diperlukan usaha untuk bisa menigkatkan kompetensi tenaga pendidik di Indonesia.

Kompetensi pada dasarnya adalah ke- mampuan yang dapat dilaksanakan individu dalam melaksanakan tugas dengan kepemilikan pengetahuan, skill, serta perilaku yang mampu menunjang bidang tugasnya (Dafrizal, 2017). Undang-undang Nomor 14 Tahun 2005 pasal 10 
mengenai Guru dan Dosen, memaparkan bahwa kompetensi guru terdiri atas kompetensi kepribadian, sosial, profesional, dan pedagogik. Direktur Jenderal Guru dan Tenaga Kerja menyatakan bahwa masalah kompetensi guru bukan terletak pada kompetensi guru dalam menguasai konten pembelajaran, melainkan pada kompetensi guru dalam menguasai proses pembelajaran atau pedagogik dengan baik (https://edukasi.kompas.com). Hal ini menandakan bahwa kompetensi pedagogik ialah faktor penting yang dapat memengaruhi tingkat kompetensi seorang guru.

Kompetensi pedagogik yang menjadi faktor penting dalam mendidik, maka mahasiswa calon guru diharapkan memiliki kualitas kompetensi pedagogik yang baik. Peningkatan kualitas kom- petensi pedagogik dalam keterlaksanaan pem- belajaran dapat dipengaruhi oleh faktor internal maupun eksternal. Faktor internal yang dapat memengaruhi kompetensi pedagogik antara lain ialah pengalaman mendidik, tingkat pendidikan, pelatihan, motivasi, serta etos kerja (Warabsari, 2018; Amelia, 2015; Nurmayuli, 2020). Semen- tara faktor eksternal yang memengaruhi kom- petensi pedagogik ialah iklim, ketersediaan sarana prasarana, lingkungan (Nurmayuli, 2020; Ismail, 2015).

(Putro, 2016) dalam penelitiannya menjelas- kan bahwasanya kompetensi pedagogik ialah kepiawaian guru dalam mengelola aktivitas pembelajaran. Sementara (Suyanto \& Jihad, 2013) menafsirkan bahwasanya kompetensi pedagogik ialah kecakapan guru dalam merencanakan, menjalankan, serta mengevaluasi pembelajaran. Jadi, kompetensi pedagogik dapat diartikan sebagai kepiawaian dalam mendidik siswa serta mengorganisasi pembelajaran yang berkenaan dengan perencanaan, pelaksanaan, serta evaluasi pembelajaran.

(Tridiana \& Rizal, 2020) menyatakan bahwa pada abad 21 tiap individu dituntut untuk memiliki keterampilan 4C (creativity, critical thinking, communication, and collaboration). Disini guru memiliki peran untuk meningkatkan keterampilan 4C siswa. Keterampilan 4C sudah semestinya dimplementasikan dalam pendidikan abad 21. Keterampilan abad 21 dapat diterapkan dalam perencanaan pembelajaran, pelaksanaan pembelajaran, sampai evaluasi pembelajaran, sehingga penentuan metode, media, dan pe- ngelolaan kelas benar-benar dapat meningkatkan keterampilan abad 21 siswa.

Mahasiswa calon guru dalam usahanya meningkatkan kompetensi pedagogik abad 21 dapat dilakukan dengan memperdalam pe- ngetahuan, pemahaman, keterampilan, nilai, sikap, dan minat terhadap pedagogik abad 21. Tingkatkan kompetensi pedagogik abad 21 menjadi salah satu tugas mahasiswa calon guru. Mahasiswa diharapkan mampu menyesuaikan diri terhadap perkembangan ilmu pengetahuan, Information and Communication Technology (ICT), serta memahami kompetensi pedagogik abad 21.

Pengetahuan yang menjadi dasar dari adanya kompetensi, maka mahasiswa calon guru selama masa perkuliahan diharapkan dapat memperdalam pengetahuan pedagogiknya. Kompetensi peda- gogik seorang guru dipengaruhi oleh tingginya pedagogical knowledge. Pedagogical knowledge merupakan pengetahuan untuk mengadaptasi dan mempelajari metode-metode, memahami strategi pembelajaran baru dengan kebutuhan siswa, dan memahami teknologi pembelajaran yang saat ini sedang berkembang. Pedagogical knowledge bermanfaat sebagai bekal pengetahuan mahasiswa calon guru saat terjun di pendidikan. Sehingga ketika menjadi seorang guru mereka telah siap dengan kompetensi pedagogik abad 21. Pedagogical knowledge didapatkan mahasiswa Prodi S1 PTI UM melalui mata kuliah kependidikan. 
Mahasiswa S1 PTI yang juga difokuskan untuk manjadi guru vokasi, kemampuan keteknikan menjadi kemampuan yang sangat dibutuhkan untuk menunjang kompetensi pedagogik abad 21. Kemampuan keteknikan harus diketahui, dimiliki, dan kuasai oleh mahasiswa PTI. Kemampuan keteknikan merupakan kemampuan yang digunakan seseorang dalam menyelesaikan tugas sesuai dengan metode, prosedur, proses, dan teknik untuk mencapai tujuan tertentu (Suprihatiningsih, 2015). Kemampuan keteknikan juga dibutuhkan bagi seorang individu maupun kelompok dalam menyelesaikan permasalahan secara teknis.

Kemampuan keteknikan yang dibutuhkan oleh mahasiwa PTI tentunya kemampuan teknis yang berhubungan dengan bidang informatika, seperti teknologi, jaringan, rekayasa, atau multimedia dalam pengerjaan suatu tugas maupun proyek. Mahasiswa S1 PTI yang juga difokuskan sebagai calon guru vokasi mendapatkan ke- mampuan keteknikan dengan mengikuti mata kuliah keteknikan selama perkuliahan.

Oleh sebab itu, kemungkinan kemampuan keteknikan dan pedagical knowledge memiliki pengaruh dengan kompetensi pedagogik abad 21 pada mahasiswa calon guru program studi S1 PTI FT UM. Ketika seorang mahasiswa calon guru memiliki kemampuan keteknikan dan pedagogical knowledge yang baik maka tidak menutup kemungkinan terjadinya peningkatan kompetensi pedagogik. Tujuan penelitan antara lain ialah: (1) mengungkap signifikansi hubungan parsial antara kemampuan keteknikan dengan kompetensi pedagogik abad 21; (2) mengungkap signifikansi hubungan parsial antara pedagogical knowledge dengan kompetensi pedagogik abad 21; (3) mengungkap signifikansi hubungan secara simultan antara kemampuan keteknikan dan pedagogical knowledge dengan kompetensi pedagogik abad 21.

\section{Metode}

Metode penelitian yang digunakan adalah expost facto dengan rancangan deskriptif korelasional yang bersifat kuantitatif. Penelitian korelasional dipergunakan untuk mengungkap hubungan antara kemampuan keteknikan (X1), pedagogical knowledge (X2), dengan kompetensi pedagogik abad 21 (Y). Populasi yang dipergunakan dalam penelitian ialah mahasiswa S1 PTI UM angkatan 2016 dengan total 107 mahasiswa. Berdasarkan data populasi yang didapatkan maka teknik sampling yang digunakan pada penelitian ini adalah purposive sampling. Purposive sampling ialah metode penentuan sampel yang dilakukan dengan mempertimbangkan dan menyeleksinya secara khusus (Siyoto \& Sodik, 2015). Sampel penelitian dimaksudkan pada mahasiswa calon guru program studi S1 PTI UM angkatan 2016 yang telah melaksanakan KPL tahun ajaran 2019/2020 sejumlah 102 mahasiswa.

Teknik pengambilan data variabel kemam- puan keteknikan dan pedagogical knowledge menggunakan teknik dokumentasi daftar nilai akhir mata kuliah keteknikan dan kependidikan. Sedangkan variabel kompetensi pedagogik abad 21, teknik pengambilan data menggunakan kuesioner skala likert dengan memeroleh nilai reliabilitas sebesar 0,988. Teknik analisis data menggunakan uji asumsi klasik, analisis korelasi parsial dan regresi berganda, dan analisis sumbangan prediktor berbantuan aplikasi SPSS Statistic 22.0.

\section{Hasil dan Pembahasan}

Tabel 1 memerlihatkan hasil deskripsi data pada variabel kompetensi pedagogik abad 21 mahasiswa calon guru S1 PTI UM berada pada kategori tinggi dengan sejumlah 46 responden $(45,10 \%)$, serta diperoleh rata-rata 274,59 , dengan skor tertinggi 347 , untuk skor terendah adalah 209. 
Tabel 1. Distribusi Data Variabel Kompetensi Pedagogik Abad 21

\begin{tabular}{lllll}
\hline No. & Klasifikasi & Interval (i) & F & $\%$ \\
\hline 1. & Sangat Tinggi & $280-350$ & 43 & 42,16 \\
2. & Tinggi & $233,33-280$ & 46 & 45,10 \\
3. & Sedang & $186,67-233,33$ & 13 & 12,75 \\
4. & Rendah & $140-186,67$ & 0 & 0,00 \\
5. & Sangat Rendah & $70-140$ & 0 & 0,00 \\
\hline & & Total & 102 & 100 \\
\hline
\end{tabular}

Tabel 2 memerlihatkan hasil deskriptif data pada variabel kemampuan keteknikan mahasiswa calon guru S1 PTI UM berada pada kategori sedang dengan sejumlah 42 responden $(41,18 \%)$, serta diperoleh rerata sebesar 78,53 , dengan skor tertinggi 87 , dan skor terendah 68.

Tabel 2. Distribusi Data Variabel Kemampuan Kateknikan

\begin{tabular}{lllll}
\hline No. & Klasifikasi & Interval (i) & $\mathrm{F}$ & $\%$ \\
\hline 1. & Sangat Tinggi & $84-87$ & 12 & 11,76 \\
2. & Tinggi & $80-83$ & 31 & 30,39 \\
3. & Sedang & $76-79$ & 42 & 41,18 \\
4. & Rendah & $72-75$ & 14 & 13,73 \\
5. & Sangat Rendah & $68-71$ & 3 & 2,94 \\
\hline & & Total & 102 & 100 \\
\hline
\end{tabular}

Tabel 3 memerlihatkan hasil deskriptif data pada variabel pedagogical knowledge mahasiswa calon guru S1 PTI UM berada pada kategori sangat tinggi dengan sejumlah 38 responden $(37,25 \%)$, diperoleh rerata sebesar 83,26 , dengan skor tertinggi 88 , dan skor terendah 76.

Tabel 3. Distribusi Data Variabel Pedagogical Knowledge

\begin{tabular}{lllll}
\hline No. & Klasifikasi & Interval (i) & F & $\%$ \\
\hline 1. & Sangat Tinggi & $280-350$ & 43 & 42,16 \\
2. & Tinggi & $233,33-280$ & 46 & 45,10 \\
3. & Sedang & $186,67-233,33$ & 13 & 12,75 \\
4. & Rendah & $140-186,67$ & 0 & 0,00 \\
5. & Sangat Rendah & $70-140$ & 0 & 0,00 \\
\hline & & 102 & 100 \\
\hline
\end{tabular}

Uji asumsi klasik yang terdiri atas uji normalitas, uji linearitas, uji multikolinearitas, uji autorelasi, dan uji heteroskedastisitas. Uji normalitas dengan metode kolmogorof-smirnov variabel X1, X2, serta Y memeroleh nilai p secara berurutan sebesar 0,2;0,2;0,092. Berlandaskan hasil uji normalitas yang diperoleh maka data dikatakan normal. Karena nilai $\mathrm{p}$ dari ketiga variabel lebih besar dari 0,05.

Uji linearitas yang dilakukan antara variabel kemampuan keteknikan dengan kompetensi pedagogik abad 21 memeroleh nilai deviation from linearity sebesar 0,660. Sementara pedagogical knowledge dengan kompetensi abad 21 memeroleh nilai deviation from linearity sebesar 0,053. Uji linearitas yang dilakukan dengan memertimbangkan 
nilai deviation from linearity dikatakan linear jika nilai $p>0,05$. Dari hasil tersebut maka dapat disimpulkan bahwa kemampuan keteknikan dengan kompetensi pedagogik abad 21, serta pedagogical knowledge dengan kompetensi abad 21 hubungannya ialah linear.

Berdasarkan hasil uji multikolinearitas, variabel kemampuan keteknikan dan pedagogical knowledge memperoleh nilai tolerance sebesar 0,519 serta nilai VIF sebesar 1,926. Jika ditinjau dari hasil uji multikolinearitas yang dilakukan maka dapat diketahui bahwa tidak terjadi multikolinearitas antara kemampuan keteknikan dan pedagogical knowledge. Karena nilai tolerance kedua variabel lebih besar dari 0,1, serta nilai VIF kurang dari 10,00.

Uji autokorelasi antar variabel diuji dengan menggunakan Durbin-Watson. Hasil uji korelasi antar variabel didapatkan nilai d (durbin-watson) sebesar 2,008. Dasar pengambilan keputusan uji ini adalah ketika nilai $\mathrm{dU}<\mathrm{d}<4-\mathrm{dU}$ maka tidak terjadi autokorelasi. Pada tabel Durbin Watson dengan sampel berjumlah $102(\mathrm{n}=102)$ dan variabel bebas berjumlah $2(\mathrm{k}=2)$ dengan taraf signifikansi 5\%, maka didapatkan nilai $\mathrm{dL}=1,6376, \mathrm{dU}=1,7175$, dan nilai 4-dU = 2,2825 .

Melalui dasar pengambilan keputusan uji D-W didapatkan hasil 1,7175 $<2,008<2,2825$, maka kesimpulannya ialah tidak terjadi autokorelasi. Hasil uji heteroskedastisitas yang dilakukan dengan menggunakan scatterplot didapatkan simpulan bahwa tidak terjadi gejala heteros- kedastisitas, karena pada grafik scatterplot titik- titik tidak membentuk pola atau tidak beraturan, titik- titik menyebar di atas dan di bawah titik 0 , serta tidak mengumpul diatas maupun dibawah saja.

Hasil uji hipotesis pertama didapatkan nilai p kolom Sig. variabel kemampuan keteknikan dengan kompetensi pedagogik abad 21 men- dapatkan nilai sebesar 0,930 ( $\mathrm{p}>$ $0,05)$, yang menandakan tidak terjadinya hubungan yang signifikan antara kedua variabel. Sementara untuk koefisien korelasi didapatkan nilai sebesar 0,009 yang berarti terdapat hubungan positif antara variabel kemampuan keteknikan dengan kompetensi pedagogik abad 21. Jadi, uji hipotesis pertama dapat dinyatakan adanya hubungan positif namun tidak signifikan antara variabel kemampuan keteknikan dengan kompetensi pedagogik abad 21.

Hasil uji hipotesis kedua didapatkan nilai p kolom Sig. variabel kemampuan keteknikan dengan kompetensi pedagogik abad 21 men- dapatkan nilai sebesar 0,000 ( $\mathrm{p}<0,05)$, yang menandakan terjadinya hubungan yang signifikan antara kedua variabel. Sementara untuk koefisien korelasi didapatkan nilai sebesar 0,439 yang berarti terdapat hubungan positif antara variabel pedagogical knowledge dengan kompetensi pedagogik abad 21. Berbeda dengan uji hipotesis pertama, uji hipotesis kedua dinyatakan adanya hubungan positif dan signifikan antara variabel pedagogical knowledge dengan kompetensi pedagogik abad 21.

Hipotesis ketiga diuji dengan menggunakan analisis regresi berganda dan diketahui melalui tabel ANOVA. Berdasarkan hasil uji hipotesis ketiga yakni terdapat hubungan positif dan signifikan. Hal tersebut dibuktikan dengan nilai signifikansi F sebesar 0,000, yang mana nilai tersebut lebih kecil dari 0,05, maka dapat disimpulkan Ha diterima dan H0 ditolak. Nilai hasil analisis regresi berganda diperoleh nilai konstanta sebesar -251,344, sedangkan nilai koefisien regresi kemampuan keteknikan sebesar 0,08, dan pedagogical knowledge sebesar 6,241 sehingga diperoleh persamaan regresi $Y=0,080 \mathrm{X} 1+6,241 \mathrm{X} 2-251,344$. Jadi, setiap kenaikan satu satuan variabel kemampuan keteknikan dan pedagogical knowledge, maka kompetensi pedadogik abad 21 akan mengalami peningkatan $0,08+6,241$ secara simultan. 
Sumbangan yang diberikan oleh variabel kemampuan keteknikan (X1), dan pedagogical knowledge (X2) secra simultan terhadap variabel kompetensi pedagogik abad 21 (Y) sejumlah $32,11 \%$. Sumbangan efektif yang diberikan variabel kemampuan keteknikan terhadap kompetensi pedagogik abad 21 ialah sebesar $0,41 \%$. Sementara sumbangan efektif pedagogical knowledge terhadap kompetensi pedagogik abad 21 menyumbangkan nilai sebesar 31,7\%. Ren- dahnya sumbangan efektif variabel kemampuan keteknikan menurut penelitian (Putro, 2016) disebabkan karena kemampuan keteknikan bukanlah fakor utama yang diperlukan guru dalam menyampaikan materi pembelajaran. Namun, kemampuan keteknikan juga menjadi faktor yang diperlukan untuk menunjang kompetensi guru, terutama untuk guru vokasi.

Tabel 4. Hipotesis Kedua Variabel X1 dengan Y

\begin{tabular}{|c|c|c|c|c|c|}
\hline \multirow[t]{2}{*}{ No. } & \multirow{2}{*}{$\begin{array}{l}\text { Hubungan } \\
\text { parsial }\end{array}$} & \multirow{2}{*}{$\begin{array}{l}\text { Koefisien } \\
\text { Korelasi } \\
\end{array}$} & \multicolumn{2}{|c|}{ Probabilitas } & \multirow[t]{2}{*}{ Interpretasi } \\
\hline & & & Phitung & Pstandar & \\
\hline 1. & $\mathrm{X}_{1}$ dengan $\mathrm{Y}$ & 0,009 & 0,930 & 0,05 & $\begin{array}{l}\text { Positif tidak } \\
\text { signifikan }\end{array}$ \\
\hline
\end{tabular}

Tabel 5. Hipotesis Kedua Variabel X2 dengan Y

\begin{tabular}{|c|c|c|c|c|c|}
\hline \multirow[t]{2}{*}{ No. } & \multirow[t]{2}{*}{$\begin{array}{l}\text { Hubungan } \\
\text { parsial }\end{array}$} & \multirow[t]{2}{*}{$\begin{array}{l}\text { Koefisien } \\
\text { Korelasi }\end{array}$} & \multicolumn{2}{|c|}{ Probabilitas } & \multirow[t]{2}{*}{ Interpretasi } \\
\hline & & & Phitung & Pstandar & \\
\hline 1. & $\mathrm{X}_{2}$ dengan $\mathrm{Y}$ & 0,439 & 0,000 & 0,05 & $\begin{array}{l}\text { Positif dan } \\
\text { Signifikan }\end{array}$ \\
\hline
\end{tabular}

Tabel 6. Hipotesis Ketiga Variabel X1 dan X2 dengan Y

\begin{tabular}{lll}
\hline Variabel Bebas & Koefisien Regresi & Sig T \\
\hline Kemampuan Keteknikan $\left(\mathrm{X}_{1}\right)$ & 0,080 & 0,930 \\
Pedagogical Knowledge $\left(\mathrm{X}_{2}\right)$ & 6,241 & 0,000 \\
Multiple R & 0,556 & \\
Rsquare & 0,321 & \\
Fhitung & 23,387 & \\
Sig. F & 0,000 & \\
\hline
\end{tabular}

Ditijau dari hasil analisis deskriptif, maka dinyatakan bahwa sebagian besar mahasiswa S1 PTI angkatan 2016 FT UM memiliki kompetensi pedagogik abad 21 dengan kategori tinggi. Hal ini berarti mahasiswa S1 PTI angkatan 2016 memiliki kemampuan yang tinggi terkait kompetensi pedagogik abad 21. (Mulyasa, 2013) menjelaskan bahwa kompetensi merupakan suatu perpaduan antara pengetahuan, keterampilan, nilai, dan sikap yang dimiliki dalam melaksanakan tugas atau pekerjaan yang disesuaikan dengan jabatan dari seseorang. Dalam penelitian ini kompetensi pedagogik abad 21 merupakan kompetensi yang harus dimiliki oleh seseorang guru untuk mengelola pembelajaran mulai dari perencanaan hingga evaluasi pembelajaran yang disesuaikan dengan ciri khas pendidikan abad 21.

Ditinjau dari hasil analisis deskriptif, maka dinyatakan bahwa kemampuan keteknikan mahasiswa S1 PTI FT UM masuk dalam kategori sedang. Hal tersebut mengindikasikan bahwa secara kognitif mahasiswa S1 PTI angkatan 2016 memiliki bekal kemampuan keteknikan yang 
sedang. Tingkatan kemampuan mahasiswa yang belum tinggi, maka perlu adanya peningkatan kemampuan keteknikan mahasiswa S1 PTI.

Ditijau dari hasil analisis deskriptif, maka dinyatakan bahwa sebagian besar mahasiswa S1 PTI angkatan 2016 memiliki pedagogical knowledge dengan kategori sangat tinggi Hal tersebut mengindikasikan bahwa secara kognitif mahasiswa S1 PTI angkatan 2016 memiliki pengetahuan pedagogik yang sangat tinggi dengan pencapaian prestasi yang baik pada mata kuliah kependidikan.

Berdasarkan hasil analisis yang dilakukan, hasil hipotesis pertamadiketahui bahwa terdapat hubungan yang positif namun tidak signifikan antara kemampuan keteknikan dengan kompetensi pedagogik abad 21 pada mahasiswa S1 PTI FT UM dengan nilai koefisien korelasi sebesar 0,009. Hal tersebut menandakan bahwa hubungan parsial antara kemampuan keteknikan dengan kompetensi pedagogik abad 21masuk dalam ketegori sangat lemah.

Hasil hipotesis tersebut didukung oleh hasil penelitian yang dilakukan oleh Saputro. Hasil penelitian (Saputro, 2017) menyatakan bahwa kemampuan keteknikan dengan animo menjadi guru kejuruan memiliki hubungan yang positif namun tidak signifikan. Sementara, hasil penelitian yang dilakukan oleh (Amalia et al., 2018) menyatakan bahwa terjadi hubungan positif serta signifikan antara kemampuan keteknikan terhadap kinerja pegawai. Jadi, kemampuan keteknikan lebih memengaruhi kinerja di dunia industri dibandingkan dengan kompetensi pedagogik abad 21.

Berdasarkan hasil hipotesis kedua yang telah dipaparkan, terindikasi bahwa terdapat hubungan yang positif dan signifikan antara pedagogical knowledge dengan kompetensi pedagogik abad 21 pada mahasiswa S1 PTI angkatan 2016. (Kumala et al., 2018) menjelaskan bahwa ketika seorang guru melaksanakan tugas berdasar- kan pengetahuan, tindakan tersebut akan mening- katkan kemampuan menuju tahap selanjutnya yang mana dalam penelitian ini ialah kompetensi pedagogik.

Hasil hiptesis kedua juga didukung oleh penelitian (Firiyah et al.,2018), hasil penelitiannya menjelaskan bah- wasanya terdapat hubungan positif antara pengetahuan pedagogik terhadap persepsi berkari sebagai seorang guru. Sehingga, dapat dipastikan bahwa pedagogical knowledge yang didapatkan mahasiswa melalui kegiatan perkuliahan akan memengaruhi kompetensi pedagogik abad 21 yang merupakan salah satu persyaratan sebagai guru profesional.

Berdasarkan hasil hipotesis ketiga yang telah dipaparkan, maka dapat dipastikan adanya hubungan yang positif dan signifikan antara kemampuan keteknikan dan pedagogical knowledge secara simultan dengan kompetensi pedagogik abad 21 pada mahasiswa S1 PTI angkatan 2016. Berdasarkan pada pembehasan kajian teori sebelumnya kemampuan keteknikan dan pedagogical knowledge merupakan aspek yang dapat memengaruhi tingkat kompetensi pedagogik abad 21 pada mahasiswa S1 PTI FT UM angkatan 2016.

Ditinjau dari penelitian yang dilakukan oleh (Putro, 2016) menunjukkan bahwa pengetahuan pedagogik dan pengetahuan keteknikan memiliki hubungan yang positif dan signifikan dengan kemampuan adaptasi mahasiswa calon guru SI PTE FT UM. Penelitian ini menunjukkan bahwa pengetahuan pedagogik dan pengetahuan keteknikan memiliki pengaruh terhadap kemampuan adaptasi mahasiswa calon guru. Selaras dengan hasil penelitian 
tersebut, penelitian ini menunjukkan bahwa kemampuan keteknikan dan pedagogical knowledge memiliki hubungan dengan kompetensi pedagogik abad 21. Namun, untuk variabel kemampuan keteknikan yang secara parsial tidak memiliki hubungan yang signifikan dengan kompetensi pedagogik abad 21. Hal tersebut menjadikan kemampuan keteknikan memerlukan faktor lain agar dapat memiliki hubungan yang signifikan dengan kompetensi pedagogik abad 21.

\section{Simpulan}

Kompetensi pedagogik abad 21 mahasiswa calon guru S1 PTI UM dikategorikan tinggi dengan persentase sebesar 45,10\%. Kemampuan keteknikan mahasiswa calon guru S1 PTI UM dikategorikan sedang dengan persentase sebesar 41,18\%. Pedagogical knowledge mahasiswa calon guru S1 PTI UM dikategorikan sangat tinggi dengan persentase sebesar 37,25\%; Kesimpulan dari penelitian korelasi antara kemampuan keteknikan dan pedagogical knowledge dengan kompetensi pedagogik abad 21 pada mahasiswa calon guru S1 PTI UM ialah: (1) terdapat hubungan positif dan namun tidak signifikan secara parsial kemampuan keteknikan dengan kompetensi pedagogik abad 21; (2) terdapat hubungan positif dan signifikan secara parsial pedagogical knowledge dengan kompetensi pedagogik abad 21; (3) terdapat hubungan secara simultan yang positif dan signifikan kemampuan keteknikan dan pedagogical knowledge dengan kompetensi pedagogik abad 21. Sementara untuk sumbangan efektif dari variabel kemampuan keteknikan dan pedagogical know- ledge dengan kompetensi pedagogik abad 21 ialah $32,11 \%$.

\section{Daftar Rujukan}

Amelia, R. C. 2015. Faktor-Faktor yang Memengaruhi Kompetensi Pedagogik dan Kompetensi Profesional Guru Biologi SMA Se-Kota Tebing Tinggi. (Master's Thesis) Universitas Negeri Medan, Medan, Indonesia.

Dafrizal, J. 2017. Mempersiapkan Mahasiswa Calon Guru Generasi Digital Native dengan Teknologi. Saintifika Islamica. Jurnal Kajian Keislaman, 4(2), 151-180.

Fitriyah, F., Putro, S. C., \& Widiyaningtyas, T. (2018). Hubungan Pengetahuan Pedagogik Mahasiswa dan Keteladanan Guru Saat Kajian Praktik Lapangan dengan Persepsi Berkarir Sebagai Guru Bagi Mahasiswa Prodi S1 PTI UM. JP (Jurnal Pendidikan): Teori dan Praktik, 3(2), 74-79.

Darimi, I. (2015). Peningkatan Kompetensi Pedagogik Guru PAI dalam Pembelajaran. Jurnal MUDARRISUNA: Media Kajian Pendidikan Agama Islam, 5(2), 309-324.

Kumala, V. M., Susilo, J., \& Susanto, R. 2018. Hubungan Pengetahuan Pedagogik dengan Kompetensi Pedagogik Serta Perbedaannya di Sekolah Negeri dan Sekolah Swasta. Prosiding SNIPMD, 170-181.

Mulyasa, E. 2013. Standar Kompetensi Guru dan Sertifikasi Guru. Bandung: PT Remaja Rosdakarya.

Yuli, N. (2020). Faktor-faktor yang mempengaruhi Kompetensi Pedagogik Guru. Jurnal Al Mabhats, 5(1), 77103.

Putro, S. C. (2016). Pengetahuan Pedagogik dan Keteknikan sebagai Prediktor Kemampuan Adaptasi Calon Guru pada Mahasiswa Jurusan Teknik Elektro FT UM. Teknologi dan Kejuruan: Jurnal teknologi, Kejuruan dan Pengajarannya, 39(1), 1-10.

Redhana, I. W. 2019. Mengembangkan Keterampilan Abad ke-21 dalam Pembelajaran Kimia. Jurnal Inovasi Pendidikan Kimia, 13(1), 2239-2253.

Saputro, D.R. 2017. Hubungan antara Etos Kerja Melaksanakan KPL dan Kemampuan Keteknikan dengan Animo Menjadi Guru Kejuruan bagi mahasiswa Prodi S1 PTE Jurusan Teknik Elektro Fakultas Teknik Universitas Negeri Malang. Skripsi tidak diterbitkan. Universitas Negeri Malang.

Tridiana, R., \& Rizal, F. (2020). Keterampilan Guru Abad 21 di Sekolah Menengah Kejuruan (SMK). Jurnal Imiah Pendidikan dan Pembelajaran, 4(2), 221-231.

Siyoto, S. \& Sodik, M. A. 2015. Dasar Metodologi Penelitian. Yogyakarta: Literasi Media Publishing. 
Jurnal Inovasi Teknik dan Edukasi Teknologi (JITET), 1(1), 2021, 1-9

Suprihatiningsih, S. 2015. Implementasi Kurikulum Pendidikan Keterampilan Vokasi di Madrasah Aliyah. IndoIslamika, 5(2), 183- 211.

Jihad, A. (2013). Menjadi guru profesional: Strategi meningkatkan kualifikasi dan kualitas guru di era global. Penerbit Erlangga.

Warabsari, D. A. 2018. Kompetensi Pedagogik Guru ditinjau dari Pengalaman Mengajar, Beban Kerja, dan Kemampuan Teknologi Informasi dan Komunikasi Berdasarkan Survei pada Guru-Guru SMA dan SMK Negeri Se-Kabupaten Sleman Yogyakarta. Universitas Sanata Dharma, Yogyakarta, Indonesia. 